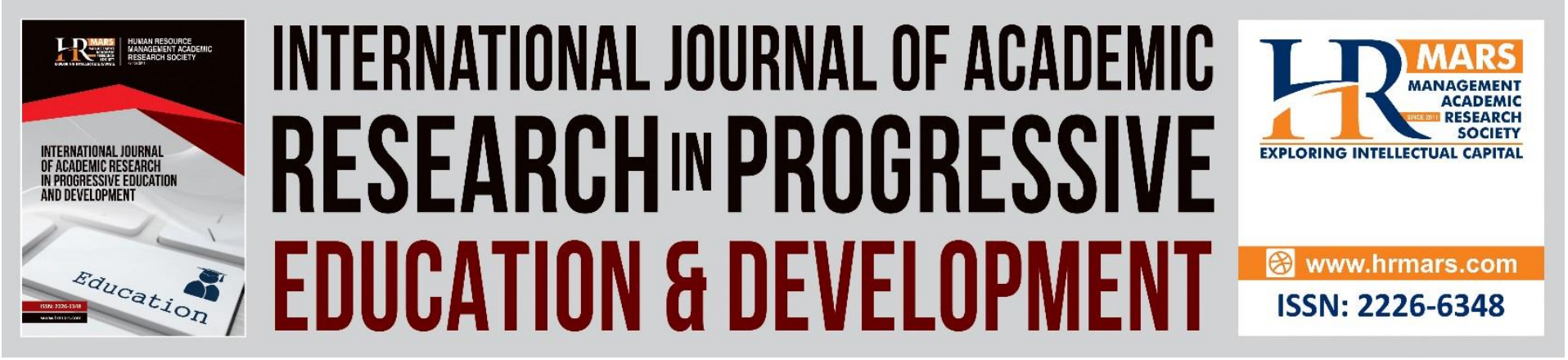

\title{
The Legitimacy of Applying the Jurisprudential Maxim "The Appellant May Not be Harmed by His Appeal" in Islamic Law and Libyan Positive Law
}

Salim Mohamed Ameer Amhalhal, Engku Muhammad Tajuddin B. Eng. Ali

To Link this Article: http://dx.doi.org/10.6007/IJARPED/v10-i3/11599

DOI:10.6007/IJARPED/v10-i3/11599

Received: 05 July 2021, Revised: 29 July 2021, Accepted: 24 August 2021

Published Online: 21 September 2021

In-Text Citation: (Amhalhal \& Ali, 2021)

To Cite this Article: Amhalhal, S. M. A., \& Ali, E. M. T. B. E. (2021). The Legitimacy of Applying the Jurisprudential Maxim "The Appellant May Not be Harmed by His Appeal" in Islamic Law and Libyan Positive Law.

International Journal of Academic Research in Progressive Education and Development, 10(3), 1275-1286.

Copyright: (C) 2021 The Author(s)

Published by Human Resource Management Academic Research Society (www.hrmars.com)

This article is published under the Creative Commons Attribution (CC BY 4.0) license. Anyone may reproduce, distribute, translate and create derivative works of this article (for both commercial and non-commercial purposes), subject to full attribution to the original publication and authors. The full terms of this license may be seen at: http://creativecommons.org/licences/by/4.0/legalcode

Vol. 10(3) 2021, Pg. 1275 - 1286

http://hrmars.com/index.php/pages/detail/IJARPED

JOURNAL HOMEPAGE

Full Terms \& Conditions of access and use can be found at http://hrmars.com/index.php/pages/detail/publication-ethics 


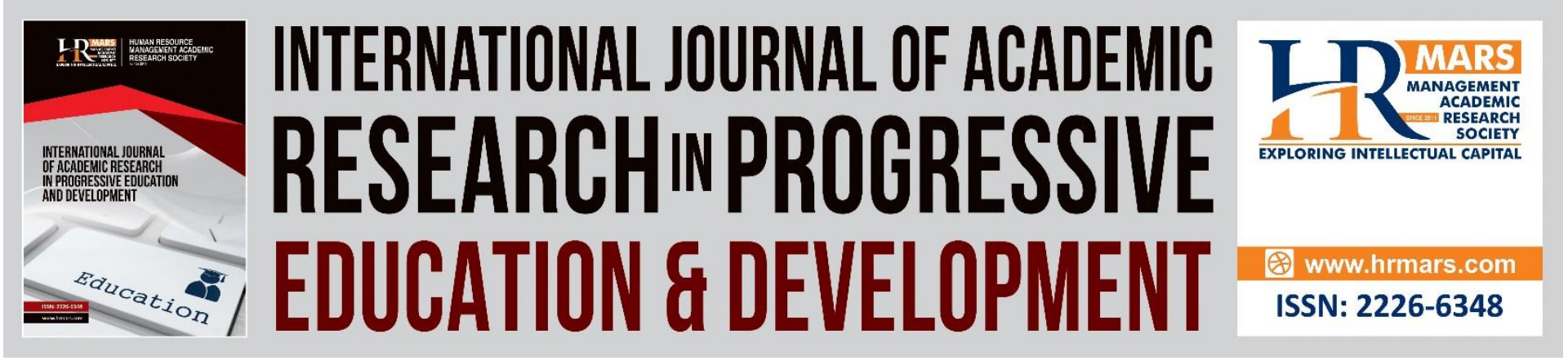

\title{
The Legitimacy of Applying the Jurisprudential Maxim "The Appellant May Not be Harmed by His Appeal" in Islamic Law and Libyan Positive Law
}

\author{
Salim Mohamed Ameer Amhalhal, Engku Muhammad Tajuddin \\ B. Eng. Ali
}

Faculty of Contemporary Islamic Studies, Universiti Sultan Zainal Abidin, Malaysia.

Corresponding Author: salem15.mohammed@gmail.com

\begin{abstract}
Following the major political incidents occurring in Libya in the last decade of the century and development in every aspect after the Libyan revolution in 2011, its legislations have developed, and many of them have changed. The research problem lies in the disagreements between the Libyan legislation that regulates the right to appeal by cassation and Islamic principles regulating this right. The study also discusses the significance of the procedural policy, whose shortcomings have prejudiced the guarantees of the maxim "the appellant may not be harmed by his appeal". This study aims to highlight the concept and legitimacy of applying the maxim "the appellant may not be harmed by his appeal" in Islamic law and Libyan positive law, as well as clarifying whether this maxim may be implemented in hudud cases. This study employed the analytical descriptive method, combining the understanding of the legitimacy of applying jurisprudential maxim in Islamic law and Libyan positive law with the goal of producing an integrated scholarly description of "the appellant may not be harmed by his appeal". The researcher compared the analyzed issues to show the points of agreements and differences between Islamic law and positive law and to achieve an optimal solution that corresponds to current development in legislation policy in order to apply Islamic jurisprudential maxims. The study concluded several findings, among them: it is not possible to apply the maxim "the appellant may not be harmed by his appeal" on a broader scale in Islamic law, unlike the case in positive law. This is because the cassation of a final and correct judicial judgment is not allowed in Islamic law. There is no Shariah barrier against the application of the maxim "the appellant may not be harmed by his appeal" in ta'zir cases, wherein the judge has the discretion to determine the sentence.

Keywords: Legitimacy, Maxim, Jurisprudential, Harm, Appellant, Islamic Law, Libyan Positive Law
\end{abstract}

\section{Introduction}

The judiciary has seen much development in recent years. Its significance has increased due to its function as an essential facility responsible for the establishment of justice in society and settlement of increasing disputes arising in it. The judiciary remains an area of 
development and research in its various principles and is influenced by economic and social transformations witnessed by society. For this purpose, judicial appeal has been legalized to address errors that may emerge in judicial judgments and to amend whatever errors that can be amended. It has been organized, despite its multiplicity, in a way that allows it to address as many of such errors as possible.

The right to appeal against judicial judgments is one of the most important rights granted by the Islamic and positive law legislator. The defendant holds the right to appeal a judicial judgment in cases specified by the Shariah and law, such as the deviation of the judge from truth or correctness, or if the judgment comes from a judge who does not fulfil the requirements to administer justice. One of the most important principles of judicial appeal is that the appellant may not be harmed by his appeal, or the objector may not be harmed by his objection, or the complainant may not be harmed by his complaint.

The researcher shall explain the concept and legitimacy of this maxim in Islamic law and Libyan positive law, with comments on some decisions of the Supreme Court of Libya issued on this subject. The study comprises three sections as follows.

\section{Conceptual Meaning of the Jurisprudential Maxim "The Appellant May Not be Harmed by His Appeal" in Islamic Law and Libyan Positive Law}

In this section, the researcher shall discuss the meaning of the maxim "the appellant may not be harmed by his appeal" in Islamic law and Libyan positive law. The discussion is as follows.

The Concept of the Maxim "The Appellant May Not be Harmed by His Appeal" in Islamic Law It is clear from the maxim, as its meaning would indicate, that a judge must not forget that a litigant files for an appeal because he perceives that the judgment has deviated from the truth or is erroneous in its evaluation, and that he seeks the re-examination of the dispute and its judgment in a manner that realizes his interest (mașlahah) in the judgment. Therefore, the appellant may not be harmed, such that he is sentenced to a more severe punishment than he was in the appealed judgment. The litigant only files a legal case to seek a benefit, which requires the appellant to have an interest in his appeal. A legal case should not be accepted if it is not filed by a person with an interest in its filing. Interest is the benefit that returns to the plaintiff following his request to the court to rule a compensation in his favor due to the harm that he was subjected to as a result of the overturned judgment. Indeed, interest is a prerequisite of every legal case. Some legal scholars define it as "the benefit gained by the plaintiff from his legal recourse". Principally, a person whose right is injured has an interest to seek legal recourse, and he also seeks benefit from such recourse. Interest, therefore, is the reason to file a legal case, and, on the other hand, is the objective thereto" (Abu al-Wafa, n.d.).

The assumed interest in legal cases must have certain distinguishing characteristics, one of which is that it is a legitimate legal interest. A proceeding, therefore, must be instituted to protect a legal interest. This means that the interest is derived from a legal right or status and aims to recognize and protect such a legal right or status (al-Qudah, 1988).

As a result of such interest, benefit is derived from the judicial judgment. The foremost of those benefits is that the appellant must not be harmed by his appeal. This maxim implies that the Court of Appeal must respect the interest of the appellant. It may not amend the trial 
judgment in such a manner that it injures the interest of the appellant. Instead, the Court either upholds the judgment or amends it in the interest of the appellant (Husni, 2019).

It is therefore understood that-based on the maxim "the appellant may not be harmed by his appeal" - the court must respect the interest of the appellant. The Supreme Court of Libya defines this maxim thus: "The meaning of the maxim 'the appellant may not be harmed by his appeal' - it is a case wherein the appeal is filed by the convicted party alone-is that following his appeal, the appellant may not be sentenced to a more severe punishment than the initial sentence before his filing of the appeal, whether in terms of a freedom-restricting penalty or fine, or in terms of the compensation to which he may be ordered in a civil action that follows a criminal action, so that the appellant is not subjected to an injury that he could have avoided had he not appealed against the judgment issued against him (Supreme Court of Libya, 1992).

After extensive research, the author was unable to obtain a direct Shari'ah reference for the maxim "the appellant may not be harmed by his appeal". However, some researchers consider this maxim as a jurisprudential maxim derived from the provisions of Islamic law. Its general meaning is that if a person challenges the procedure or a judgment issued against him, he may not be harmed by his appeal, and his sentence must not be more severe than that imposed by the initial judgment, except if the matter relates to a violation of public order and public morals (Abu al-'Ala, 2021).

It is established in the principles of justice advocated by Islamic law that the claimant may not be harmed by his claim; the objector by his objection; the complainant by his complaint; and the appellant by his appeal, except if his maliciousness and deliberate deception and misinformation are proven. It is not justice to turn the complaint or appeal of a complainant against him. Nonetheless, there are several legal exceptions for the maxim "the appellant may not be harmed by his appeal". They will be elucidated upon during the discussion on the legitimacy of the maxim's application in Islamic law.

The Concept of the Maxim "The Appellant May Not be Harmed by His Appeal" in Libyan Positive Law

The Libyan legislation has clearly stipulated the maxim "the appellant may not be harmed by his appeal". It is considered as one of the most important fundamental guarantees that govern the right to appeal a judicial judgment. The Libyan legislator stipulates in the Chapter on Objection as A Method of Appeal in the Libyan Code of Procedures, "An objection shall entail a re-examination of the case before the court that issued the judgment in absentia for the benefit of the objector. The objector may not be in any way harmed by the objection that he made" (Libya, 1951). The Code also stipulates in the Chapter on Appeal as a Method of Appeal, "If the appeal is filed by the Public Prosecution, the court may uphold, overturn, or amend the judgment against or in the interest of the defendant. The sentence may not be increased and the judgment to acquit may not be annulled except with the unanimous opinion of the judges of the Court."

The Supreme Court of Libya likewise decrees, "The legally established maxim of "the appellant may not be harmed by his appeal' only applies if the appeal is filed by the defendant alone. In the case where the appeal is also filed by the Public Prosecution, then its appeal against the judgment entails transferring the case in its entirety to the Court of Appeal and the Court's attachment to the case, such that it has the authority to examine the case in all its aspects and adjudicate it according to what it deems fit within the confines of the law and 
without being constrained by any constraints" (Supreme Court of Libya, 1979). The legislator states in the Chapter on Appeal by Cassation in the Libyan Code of Criminal Procedures, "If the cassation of a judgment is based on the request of one of the litigants other than the Public Prosecution, then he shall not be harmed by his appeal" (Libya, 1951). The Libyan legislator stipulates in the Chapter on Appeal by Rehearing in the Libyan Code of Criminal Procedures, "Judgments that are issued based on rehearing by other than the Court of Cassation may be appealed by any method of appeal prescribed in the law. The defendant may not be sentenced to a more severe punishment than the previous sentence" (Libya, 1951).

Examining the above texts, it is clear that the Libyan law includes the concept of the maxim "the appellant may not be harmed by his appeal" in every chapter of appeal against judicial judgments in various terms, for instance, "The appellant may not be harmed by his appeal, the imposed sentence may not be increased, and acquittal may not be overturned. Everything that is in the interest and for the benefit of the appellant is consistent with that maxim, while everything that increases the sentence is contradictory to its meaning." The maxim of not injuring the interest of the appellant finds its justifications and wisdoms in the following (al-Fakhiri, 2016):

1. It is a natural conclusion of appeal itself as it is regarded as a complaint. Fundamentally, one's complaint may not be turned against him, and he may not be punished for his complaint, as it is possible for the appellant to accept the judgment and not appeal it, and it is not justice that he is sentenced to a more severe punishment than that of the appealed judgment.

2. This maxim is a part of the general principles that restrict the court's authority to within what is requested from it. The appellant, upon his appeal against the judgment, intends to benefit from the judiciary; he submits his complaint to it in the hopes of realizing his interest. The court is therefore required to either accept the appeal, partially or fully annul the judgment, or reject the appeal. Thus, the court may not pass a judgment that may worsen the appellant's position; otherwise, it would exceed its authority by issuing a judgment that is not requested from it.

3. This maxim also finds its basis in the concern that a litigant may fear that an appeal could injure his interest, hence dissuading him from using this right, even though public interest may require its use to remove any compromising defect from the judgment.

\section{Legitimacy of Applying the Jurisprudential Maxim "The Appellant May Not be Harmed by His Appeal" in Islamic Law and Libyan Positive Law}

The maxim "the appellant may not be harmed by his appeal" is one of the most important fundamental procedural rules governing the consequences of appeal in general, and the consequence of appeal by cassation in particular. It is above all considerations and is legally enforceable in all cases in light of the legal text that governs it. Meanwhile, in Islamic law, there is some detail to this matter. The application of this maxim in Islamic law and Libyan positive law is discussed below.

Legitimacy of Applying the Maxim "The Appellant May Not be Harmed by His Appeal" in Islamic Law

The researcher has previously explained that this maxim is not specified in the general jurisprudential maxims of the Shari'ah that regulate the judiciary according to Islamic law. 
Nevertheless, the maxim is required by the principles of justice stipulated by Islamic law. There is no justice in turning one's complaint against him or in punishing him for it; therefore, as a general rule, one may not be punished for his complaint, and he may not be sentenced to a more severe punishment than that in the appealed judgment. If we consider the maxim of "the appellant may not be harmed by his appeal" in Islamic law, we will see that it cannot be applied unconditionally. If the initial judgment contradicts the texts of the Shariah, i.e., the Quran, Sunnah, or consensus, or is based on malice, deception, or misinformation, the maxim cannot be applied. Instead, the judge must adjudicate based on the wise provisions of the Shari'ah and in light of the actual facts and evidence available to him.

There is no Shari'ah barrier against the application of the maxim "the appellant may not be harmed by his appeal" in ta'zir cases, wherein the judge has the discretion to determine the punishment. Ta'zir, in Shari'ah, is punishment for offences not included in hudud (s. hadd; fixed punishments for certain offences). That is, it is the punishment for criminal offences for which the Shari'ah has not stipulated specific punishments. It therefore similar to hudud in an aspect, as it is a rehabilitative and deterrent punishment that differs by offence. However, it differs from hudud in two aspects:

First, every hadd has a specific punishment or punishments that must be imposed on the offender. In ta'zir, there are a set of punishments, ranging from counsel to caning, imprisonment, or even capital punishment for serious offences. It is up to the judge to choose from among this set a punishment that is appropriate for the offence and the condition, psyche, and the criminal record of the offender.

Second, the head of state (wali al-amr) cannot pardon a hadd punishment. However, he can partially or fully pardon ta'zir punishments. It is not possible to apply the maxim "the appellant may not be harmed by his appeal" in hudud offences, as the Shari 'ah has stipulated for them specific punishments. There are seven hudud offences: zina (fornication/adultery), qadhf (false imputation of zina), drinking intoxicants, theft, hirabah (banditry), riddah (apostasy), and baghy (rebellion). Because hudud punishments are determined by the Shari'ah, it is not permissible to substitute, reduce, or pardon them.

One of the barriers to apply the maxim "the appellant may not be harmed by his appeal" in hudud offences - as expounded upon by scholars - is that hudud is the right of Allah. Imam Ibn Qayyim al-Jawziyyah explains, "There are two types of rights: the right of Allah, and the right of humans. No amendment can enter the right of Allah, such as hudud, zakat, kaffarah (expiation of sin or violation), and others" (Ibn Qayyim al-Jawziyyah, 1991). Imam al-Sarakhsi states, "As for ritualistic penalties (al-'uqubat al-mahḍh), they are the hudud for which deterrence has been legally established so as to prevent the commission of their limited causes. They are purely the right of Allah, for example the hadd of zina, theft, and drinking intoxicants" (al-Sarakhsi, 1993). Unlike hudud, qișas (retributive justice) and ta'zir are not the rights of Allah. Imam Kamal ibn Humam says, "Hadd etymologically means prevention, hence haddad is used to refer to a gatekeeper (bawwab). In Shari'ah, it is a defined punishment that is the right of Allah the Exalted. Therefore, qișas is not called hadd because it is the right of the servant [i.e., human]; likewise, ta'zir is not hadd because it is not defined" (Ibn Humam, n.d.).

Initially, the Supreme Court of Libya did not apply the maxim "the appellant may not be harmed by the appeal" in hudud cases. It stressed in multiple judicial judgments to refrain from applying the maxim in hudud cases (Supreme Court of Libya, 1979). This is because hudud punishments cannot be substituted, suspended, or pardoned. Article 15 of Libyan Law 
No. 13/1423 AD on the Establishment of Hadd for Theft and Hirabah stresses the immutability and inevitability of hudud punishments, "It is not permissible to order the suspension of the enforcement of hudud punishments stipulated in this law. Likewise, it is not permissible to substitute, reduce, or pardon them" (Libya, 1425).

From the first moment that they introduced regulatory laws for hudud and qișaș offences, the Libyan legislator was guided by what has been established by the noble Islamic law. Accordingly, the Supreme Court of Libya decreed, "Hudud punishments are immutable and inevitable, pursuant to Article 15 of Law No. 13/1425 AD on the Establishment of Hadd for Theft and Hirabah, and as such it is not permissible to substitute or pardon them so long as they fulfil the conditions for their implementation. A judgment that deviates from the implementation of this law, by substituting the hadd punishment with one that has not been stipulated herein, has contradicted the correct application of the law, thus the issued judgment regarding the offence of theft must be annulled without the need to discuss what the appellant is complaining about in this regard and without taking into account the interest of the defendant in this respect" (Supreme Court of Libya, 1979).

Despite the noble intention behind this opinion, it still became a subject of extensive jurisprudential controversy. Some criticisms have been directed towards it for the following reasons (al-Fakhiri, 2007):

1. The Public Prosecution holds the right to appeal a judicial judgment. If the Public Prosecution does not appeal and only the defendant does, then the latter must enjoy the guarantees stipulated by the Code of Criminal Procedures, among which is the guarantee that the appellant may not be harmed by his appeal. The law is considered as an undivided whole, and as such it is not permissible to apply only that which harms the defendant and disregard that which can realize his interest.

2. Hudud laws are considered as specific punitive laws because they comprise independent substantive and procedural laws. It follows that the general punitive law and general procedural law do not apply to hudud laws, excepting that which has not been specified in those specific laws. The Libyan legislator does not consider the procedural laws regulated by the Code of Criminal Procedures and which are absent from hudud laws to be contradictory to Islamic law (al-Nabrawi, 1976).

Because there is no specific procedural stipulation concerning the maxim "the appellant may not be harmed by his appeal", the general procedural law-which requires the application of the maxim "the appellant may not be harmed by his appeal" - shall be referred to.

3. Not applying the maxim "the appellant may not be harmed by his appeal" in hudud laws leads to illogical and unjust consequences. If we suppose that two persons were accused of the offence of theft-which is punishable by hadd-and that each person was tried independently. The court sentenced both to ta 'zir punishments, which are two years' imprisonment and a fine of fifty dinars, despite the fact that the conditions to impose hadd had been met. The Public Prosecution did not file an appeal. A convicted defendant filed an appeal, while the other did not as he accepted the judgment. If we say that the maxim "the appellant may not be harmed by his appeal" is not applicable here, then the judgment for the convicted person who appealed will be overturned, and the case would restart at the issuing court, which would then implement the hadd law. Meanwhile, the other convicted person would still receive the ta zir sentences because 
neither he nor the Public Prosecution appealed against the judgment issued against him. This, then, is not a logical outcome and contradicts the principle of justice.

Based on the above justifications, some legal scholars maintain that the maxim "the appellant may not be harmed by his appeal" is applicable to every situation and in every case. This is what the Supreme Court of Libya ultimately refers to on the grounds that the maxim "the appellant may not be harmed by his appeal" is a general, fundamental procedural rule that is related to public order and applies to all types of appeal against judgments imposing a hadd or ta'zir punishment (al-Fakhiri, 2016). In this regard, it is stated in the Reasons of Judgment of the Supreme Court, "One of the most important guarantees of the system of judicial appeal established in the Code of Criminal Procedures is the maxim 'the appellant may not be harmed by his appeal'. If the defendant files the appeal alone, then he has the right to enjoy this guarantee. It is considered as a fundamental procedural rule that is related to public order and applies to all types of appeal against judgments imposing a hadd or ta'zir sentence, especially since the said Law No. 13/1425 has not regulated the methods of appeal against judgments. Therefore, it is a legal obligation to apply this guarantee in hudud cases. The court may not refuse its application on the grounds that the said Article 15 forbids the sentence to be substituted, reduced, suspended, or pardoned, considering that the provisions of the indicated Article are substantive laws that are the object of the Court of First Instance, and not procedural laws that refrain the implementation of this guarantee" (Supreme Court of Libya, 2009).

After examining the two decisions of the Supreme Court of Libya, the researcher maintains that the maxim "the appellant may not be harmed by his appeal" may not be applied to hudud cases. The justifications of the first decision of the Supreme Court of Libya on the subject are more accurate and stronger than its second decision. Article 15 of Law 13/1425 AD on the Establishment of Hadd for Theft and Hirabah clearly forbids negligence in hudud offences. Additionally, as we discussed previously, hudud offences are among the exclusive rights of Allah that cannot be compromised, neglected, or reduced from the Shari'ah-determined hadd. Pardon to remove hudud, the exclusive right of Allah, is also proscribed. The Prophet (pbuh) became angry when Usamah ibn Zayd (ra.) came to ask for pardon for a Makhzumi woman who had committed theft. The Mother of the Believers, 'A'isyah (ra.), narrated, "The Quraish were anxious about the Makhzumi woman who had committed theft. They said, 'Who will speak to the Apostle of Allah (pbuh) about her? Who would dare to do that other than Usamah ibn Zayd, the beloved of the Apostle of Allah (pbuh)!' So Usamah spoke to him, and the Messenger of Allah (pbuh) said, 'Are you interceding regarding one of the punishments prescribed by Allah?' He then stood up and gave an address, saying, ' $O$ people! Those who came before you were only destroyed because when one of their nobles stole, they let him off, but when one of the weak people among them stole, they would carry out the punishment on him. By Allah, if Fatimah the daughter of Muhammad were to steal, I would cut off her hand'" (al-Bukhari, 1422). Therefore, if hudud offences are proven according to the rules of evidence applicable in Islamic criminal legislation, their sentences must be executed. They cannot be suspended or pardoned on the basis of applying the legal maxim that requires the appellant to not be harmed by his appeal.

It bears mentioning that Islamic law does not intend to shed blood, cut hands, or execute Shari'ah punishments for their own sake; rather, it aims to realize its lofty objectives: protecting society from crime, deterring perpetrators, and stabilizing the Islamic state. Thus, 
Islamic law dictates that the hadd is dropped if there is doubt in the hudud offences. This a general fundamental maxim in Islamic criminal law-hudud are averted by doubts (dar' alhudud bi al-shubhat). Imam Ibn Qudamah states that jurists unanimously agree with this maxim, "Ibn Mundhir says, 'Scholars from whom we memorized unanimously agree that hudud are averted by doubts'" (Ibn Qudamah, 1990, p. 155). They infer this from a hadith narrated by the Mother of the Believers, 'A'isyah (ra.), "The Apostle of Allah (pbuh) said, "Avert hudud from Muslims as much as possible. If he has a way out then leave him to his way, for if the Imam makes a mistake in pardoning would be better than making a mistake in punishment" (al-Tirmidhi, n.d., p. 25). This hadith, despite its weak chain of narration, is still referred to by jurists in the subject of Islamic criminal law.

Legitimacy of Applying the Jurisprudential Maxim "The Appellant May Not be Harmed by His Appeal" in Libyan Positive Law

Article 397 of the Libyan Code of Criminal Procedures states, "If the cassation of a judgment is based on the request of one of the litigants other than the Public Prosecution, then he shall not be harmed by his challenge" (Libya, 1951).

Principally, in positive law, the cassation of a judgment means that it has been removed and annulled, as if it had never been issued. Therefore, the court to which the dispute is referred is not bound by the annulled judgment, and the cassation appellant may not complain about it after his request to annul the judgment has been granted. He must, then, accept the outcome reached by the court. This was the initial decision of the Egyptian Court of Cassation, before it changed it thus, "The appellant by cassation may not be harmed by his appeal." The maxim "the appellant may not be harmed by his appeal" is firmly established in the Court, since one's complaint may not be turned against him. This is also decided by the Court of Cassation and applicable to other methods of appeal as well (Husni, 2019).

In this regard, the Egyptian Court of Cassation declares, "Given that a person's complaint cannot be turned against him a priori and given that this is true in an appeal by cassation as it is true in a challenge by objection and appeal, as each of this method is a complaint through which the complainant seeks to realize his interest, and there is no valid reason to differentiate in this regard between an appeal by cassation and appeal by other methods" (Egyptian Court of Cassation, 1947).

Whenever it is possible to reconcile between a judicial judgment and not injuring the appellant, such a reconciliation must be carried out to protect the interests of the appellant and to ensure that the judicial judgment is consistent with the law. Scholars of positive law have illustrated this with a case, "If the appealed judgment imposes a sentence of imprisonment for a term less than the minimum term specified for the offence, while a sentence of a fine for this offence is discretionary, the court must sentence a fine so that the judgment is consistent with the law" (Surur, 2018).

A judicial application that confirms this principle is that if the facts of a case evince that an act of embezzlement is a consummated, not attempted, felony, as decided by the appealed judgment, and the Public Prosecution has not appealed against this judgment by cassation, the Court of Cassation cannot amend this error wherein the judgment has occurred, so that the appellant is not harmed by his appeal (Egyptian Court of Cassation, 1965).

This constraint only concerns the quantum of the sentence, thus the court to which the appeal is filed, or to which adjudication is referred to, cannot increase the sentence. However, the law does not extend to the legal characterization of the facts or to define the nature of 
responsibility placed upon it, considering that the court to which the case is referred to may emphasize the characterization of the facts without increasing the sentence. This is what the Egyptian Court of Cassation indicates with its statement, "The principle that the convicted person may not be harmed for his complaint is valid only in terms of the quantum of sentence considered as the maximum limit that cannot be surpassed by the second authority. It may not comprise other aspects, such as the evaluation of the facts of the case or giving the incident its correct description" (Husni, 2019).

The maxim is also applicable for compensation. If the appealed judgment imposes a certain amount of compensation, and the judgment is then appealed and overturned, the court to which the case is referred may not increase the amount of the compensation (Egyptian Court of Cassation, 1962). It should be noted that if the appeal is filed by the Public Prosecution, the court may increase the sentence (Egyptian Court of Cassation, 1979). As the maxim "the appellant may not be harmed by his appeal" shall not exceed the initial judgment or compensation, it shall as well not include attorney fees (Surur, 2018).

Looking at the Libyan Code of Criminal Procedures, it is clear that Article 397 recognizes the maxim "the appellant may not be harmed by his appeal", except if the appeal is filed by the Public Prosecution.

In this regard, the Supreme Court of Libya stipulates, "The aforementioned Article requires that in the cassation of a judgment, if it is based on the appeal of the defendant alone, the court to which the case is referred to may not sentence the defendant to a punishment more severe than that in the overturned sentence; this is achieved by increasing its quantum, substituting a less severe sentence with a more severe one, or revoking the suspension of its enforcement. It is established that the overturned judgment of the Supreme Court in Appeal No. (102/23Q), based on the appeal of the appellant alone, had sentenced the appellant to imprisonment with hard labor for a term of six months and a fine of fifty dinars, with an order to suspend the enforcement of the sentence of imprisonment only for the legal period. However, the Court of Second Instance to which the case is referred-and which examined the case with a new judicial panel and issued the appealed judgment-even though it had issued the same sentence as before the overturned judgment, it did not order to suspend the enforcement of the sentence of imprisonment, which means that the judgment enforced both sentences of imprisonment and fine. There was then harm to the appellant because the judgment in its description had increased his sentence, which initially ruled for the suspension of the enforcement. This matter had made the judgment contradictory to the law, which necessitates its partial cassation and amendment in this regard" (Supreme Court of Libya, 1980).

The Supreme Court of Libya also decrees, "And whereas the aforementioned Article requires that the judgment issued based on the appeal of the defendant alone-regardless of whether it is issued by the Court of Cassation or the Court of First Instance following the cassation of the judgment and the remand of the case to the Court-must not be more severe than the appealed judgment. The new judgment is considered more severe by looking at the nature or quantum of sentence: imprisonment is more severe than detention, even if its term is shorter, and likewise detention is more severe than a fine. If the sentences of the two judgments are quantitatively similar, the more severe of them is that with the larger quantum.

And whereas, although capital punishment is the most severe sentence, and that adding other sentence to it will not increase its severity, it is achieved if the execution of the capital punishment is inevitable. The head of state has no right to substitute it with another sentence. 
If the laws authorize the head of state to substitute the capital punishment with a less severe sentence, the defendant in this case is harmed by the new sentence that is not imposed on him in the judgment that he appealed against" (Supreme Court of Libya, 1971).

One of the interests prescribed by the law for the litigants based on the maxim "the appellant may not be harmed by his appeal" is that the court has the right to overturn a judgment on its own if it finds that it contradicts the law; discovers an error in the implementation or interpretation of the law or judicial procedures by the court that issued the judgment, as if there had been no issues, in accordance to the law, or if it has no jurisdiction to adjudicate the case; or if a law applicable to the case under appeal is introduced after the appealed judgment (Abu Khațwah, 1987).

Fundamentally, the maxim forbidding the appellant from being harmed by his appeal is not applicable if the appeal is requested by the Public Prosecution. This is based on Article 397 of the Libyan Code of Criminal Procedures. This is also because the Public Prosecution holds the power to prosecute; it is responsible for criminal cases, and the legislator has mandated it, on behalf of society, to initiate and prosecute a criminal action so as to punish the perpetrators, and appeal against judgments so that the perpetrator does not evade punishment and the innocent is not held guilty" (Supreme Court of Libya, 1974).

As a corollary of that, the power of the Court of Cassation expands when the appeal is requested by the Public Prosecution, whereby it has the right to overturn a judgment or set out to amend or repeal it, whether for the benefit of the defendant or otherwise. In other words, it is not restricted by the said maxim" (al-Fakhiri, 2016).

Since the Public Prosecution represents public interest and seeks to realize the provisions of the law, it holds the right to appeal against judgments, even if it, as the prosecuting authority, has no interest in such an appeal, such as if the appealed judgment is issued in accordance with its requests" (Supreme Court of Libya, 1973).

Nonetheless, it bears mentioning that there are two cases where, despite the Public Prosecution's appeal by cassation, the maxim "the appellant may not be harmed by his appeal" still applies:

First case: If the Public Prosecution appeals in the interest of the defendant, and the judgment is subsequently overturned, the referral court cannot impose a more severe sentence than that of the overturned judgment, as the defendant must not be harmed by an appeal filed in his interest. The referral court must acquit the defendant, amend the judgment according to his interest, or, in the worst case, uphold the previous sentence without increasing it.

Second case: If the convicted person by himself appeals against a partial judgment that convicts and sentences him, and then the appeal judgment affirms the appealed judgment; but, the Public Prosecution, not satisfied with the last judgment, appeals against it by cassation, which results in the cassation of the appealed judgment. In this case, the Court of Cassation or referral court must not sentence the defendant to a more severe punishment than that of the partial judgment, which the Public Prosecution did not appeal against. This is because it is the appeal of the defendant that allows the Public Prosecution to file an appeal by cassation, and as such the appellant shall not be harmed by its appeal (al-Fakhiri, 2016).

\section{Conclusion}

The maxim "the appellant may not be harmed by his appeal" is a well-established fundamental judicial principle. It is a necessary restriction for every court that exercises 
control over the judgments of lower courts. The jurisprudence and judiciary have established that this maxim is one of the rules of natural justice, which is a deep-rooted and established part of the legal system, even if the legislator does not specify it in its laws and legislations.

\section{Findings}

1. The maxim "the appellant may not be harmed by his appeal" cannot be applied on a larger scale in Islamic law, unlike the case in positive law. This is because the cassation of a final and correct judicial judgment is not possible in Islamic law.

2. The maxim "the appellant may not be harmed by his appeal" in Islamic law is not applied unconditionally. The judge must adjudicate according to the wise provisions of the Shari'ah and in light of the actual facts and evidence available to him.

3. Initially, the Supreme Court of Libya did not apply the maxim "the appellant may not be harmed by his appeal" in hudud cases. It eventually reconsidered this view and sanctioned its application in every appeal, including appeals concerning hudud cases.

4. There is no Shari'ah barrier to the application of the maxim "the appellant may not be harmed by his appeal" in ta zir cases, wherein the judge has the discretion to determine the punishment.

5. The maxim "the appellant may not be harmed by his appeal" must not be applied in hudud cases. It is necessary that the Supreme Court of Libya issues a legal rule to emphasize this.

\section{References}

Abu al-Wafa, A. (N.D). Al-Murafa'at al-Madaniyyah wa al-Tijariyyah. Alexandria: Mansha'ah al-Ma'arif.

Abu Khațwah, A, K. (1987). Al-Aḥkam al-Jina'iyyah al-Ghiyabiyyah: Dirasah Taḥliliyyah Muqaranah. Cairo: Dar al-Nahdah al- 'Arabiyyyah.

Al-Bukhari, M. I. (2000). Șahị al-Bukhari. Cairo: Dar Tawq al-Najah.

Al-Fakhiri, M. (2016). Athar al-Ṭa'n bi al-Naqụ fi al-Mawad al-Jina'iyyah. Benghazi. Libya: Dar al-Kutub al-Wațaniyyah.

Al-Nabrawi, M. S. (1976). Aḥkam Tashri'at al-Ḥudud. Benghazi. Libya: al-Maktabah alWațaniyyah.

Al-Quḍah, M. (1988). Ușul al-Muḥakamat al-Madaniyyah wa al-Tanẓim al-Qaḍa'i. Amman: Dar al-Karmal.

Al-Sarakhsi, M. A. (1993). Ușul al-Sarakhsi. Beirut: Dar al-Kutub al-'Ilmiyyah.

Al-Tirmidhi, M. (N.D). Sunan al-Tirmidhi. Beirut: Dar Ihya' al-Turath al-'Arabi.

'Awdah, Q. (N.D). Al-Tashri' al-Jina'i al-Islami Muqaranan bi al-Qanun al-Waḍ'i. Beirut: Dar alKitab al-'Arabi.

Ḥusni, M. N. (2019). Sharḥ Qanun al-ljra'at al-Jina'iyyah Wifqan li Ahdath al-Ta'dilat. Cairo: Dar al-Nahdah al-'Arabiyyah.

Ibn Humam, K. (N.D). Fath al-Qadir. Cairo: Dar al-Fikr.

Ibn Qayyim M. (1991). I'lam al-Muwaqqi in 'an Rabb al-'Alamin. Beirut: Dar al-Kutub al'Ilmiyyah.

Ibn Qudamah, M. (1990). Al-Mughni. Cairo: Dar al-Hijrah.

Surur, A. F. (2018). Al-Wasiț fi al-Naqụ al-Jina'i. Cairo: Dar al-Nahḍh al- 'Arabiyyah. 